\section{Frequency of regulatory B cells phenotypes in breast cancer patients in Egypt}

\author{
Sherein G. Elgendy ${ }^{1}$, Ehsan MW. El-Sabaa ${ }^{2}$, Shabaan \\ H. Ahmed ${ }^{1}$, Samir SM. Eid ${ }^{3}$ and Mohamed A. El- \\ Feky $^{1}$
}

${ }^{1}$ Department of Medical Microbiology \& Immunology, Faculty of Medicine, Assiut University, Assiut, Egypt.

${ }^{2}$ Department of Microbiology \& Immunology, Faculty of Pharmacy, Assiut University, Assiut, Egypt.

${ }^{3}$ Department of Clinical Oncology \& Nuclear Medicine, Faculty of Medicine, Assiut University, Assiut, Egypt.
The Egyptian Journal of Immunology

Volume 28 (1), 2021: 12-22

www.Ejimmunology.org

\begin{abstract}
Accumulating evidence has indicated that immune regulatory cells are involved in the establishment of the anti-tumor activity, however; the role of regulatory B cells (B-regs) in breast cancer (BC) remains unclear. This study intended to assess the frequency of peripheral B-regs phenotypes in patients with $\mathrm{BC}$, and to determine the relation between these phenotypes and the patient's clinicopathological characters. The expressions of the immune cell populations were analyzed by four-color flow cytometry in 40 naïve BC patients and 10 age-matched apparently healthy individuals as controls attending the department of Clinical Oncology and Nuclear Medicine at Assiut University Hospitals. The percentages of B-regs phenotypes CD $19^{+} I L 10^{+}$and $\mathrm{CD} 19^{+} \mathrm{CD} 24^{\mathrm{hi}} \mathrm{CD} 27^{+} \mathrm{IL} 10^{+}$were higher in $\mathrm{BC}$ patients than in the controls. The percentage of $\mathrm{CD} 19^{+} \mathrm{IL} 10^{+} \mathrm{B}$ cells phenotype was significantly associated with the HER-2 expression levels, $\mathrm{T}$, and $\mathrm{N}$ stages of $\mathrm{BC}$. In conclusion, high percentage of B-regs phenotypes $\mathrm{CD} 19^{+} \mathrm{IL} 10^{+}$and $\mathrm{CD} 19^{+} \mathrm{CD} 24^{\text {hi }} \mathrm{CD} 27^{+} \mathrm{IL} 10^{+}$in $\mathrm{BC}$ patients indicates a possible role in immune suppression during the development of $B C$.
\end{abstract}

Keywords: Breast cancer; Clinicopathological characteristics; regulatory B cell; interleukin-10.

Date received: 23 January 2021; accepted: 22 April 2021

\section{Introduction}

In Egypt, the National Cancer Institute reported that breast cancer $(\mathrm{BC})$ is the most common site of cancer in women and accounts for about $38.8 \%$ of total malignancies among Egyptian females. ${ }^{1} \mathrm{BC}$ is the most common malignancy in women in the United States and is second only to lung cancer as a cause of cancer death. ${ }^{2}$ The risk of developing breast cancer throughout life is $12 \%{ }^{3}$

The role of the immune system in prevention of tumors has been studied over years. It could specially identify and eliminate tumor cells through the tumor-associated antigens (TAA) or molecules expressed by the tumor cells. This process was described as tumor immune surveillance or tumor immunoediting. ${ }^{4}$

The role of T-cell-mediated immune responses in solid tumors is well established and has become the driving force for major therapeutic advances. In contrast, the knowledge of B-cell biology in cancer is less well developed. ${ }^{5}$ 
B cells can potentially inhibit the development and progression of cancers by making antitumor antibodies or by differentiating into appropriate effector B-cell states. B-cell-derived antibodies play an essential role in protection against tumor development by helping to clear oncogenic viruses before they can become established and initiate tumor development. An excellent example of this is the use of human papillomavirus (HPV) vaccines to prevent cervical cancer. ${ }^{6,7}$

However, in 2002, Mizoguchi and collaborators discovered a subset of $B$ cells called B-regulatory cells (B-regs), identified as IL-10 producing $\mathrm{B}$ cells. ${ }^{8}$ B-regs perform immunosuppressive functions by responding to signals from the tumor microenvironment that promote tumor growth via interactions with different immune cells as $T$ regulatory cells ( $T$ regs), tumor-associated macrophages, $\mathrm{CD}^{+}$and $\mathrm{CD}^{+} \quad \mathrm{T}$ lymphocytes, myeloid-derived suppressor cells (MDSC), natural killer (NK) cells, and enhancing down-regulatory immune functions by production of $\mathrm{IL}-10$ and/or transforming growth factor beta (TGF- $\beta$ ). ${ }^{7,9}$

There are no specific markers to identify different phenotypes of B-regs, but most of human B-regs were found to be originated from transitional $\mathrm{CD} 24^{\mathrm{hi}} \mathrm{CD} 38^{\mathrm{hi}}$ and memory $\mathrm{CD} 24^{\mathrm{hi}} \mathrm{CD} 27^{+}$B cells. ${ }^{10}$ Although, there are different markers used in identification of $\mathrm{B}$ regs, but IL-10 secretion is still a vital marker. ${ }^{11}$ $B$ regulatory cells could suppress the proliferation of $\mathrm{CD}^{+} \mathrm{T}$ cells and enhance FoxP3 and cytotoxic T-lymphocyte antigen 4 (CTLA-4) expressions in T-reg cells by producing IL-10 and TGF- $\beta$. B-regs did not belong to any clearly defined $B$ cell subsets but they added value in both the $\mathrm{CD} 27^{+}$and the $\mathrm{CD} 38^{\text {hi }}$ compartments. ${ }^{10,12}$

Although most B-regs studies have focused on autoimmune mouse models and patients with autoimmune diseases, several mouse studies of cancer have also revealed the existence of protumorigenic B-regs. ${ }^{13}$

At present, the subset composition and function of B-regs in human cancer including BC are largely unclear. Also, there was no previous study in Egypt detecting B-regs phenotypes in BC patients. Therefore, we undertook the present study to evaluate the frequency of peripheral B-regs in BC patients in Egypt. Also, to determine the relation between B-regs phenotype and the clinicopathological characters of $B C$ patients.

\section{Subjects and Methods}

\section{Study design}

This case-control study was carried out at the Medical Research Center, Faculty of Medicine, Assiut University. It included 50 subjects; 40 naïve breast cancer patients and 10 age matched apparently healthy individuals as controls. Patients were selected based on the following criteria: naïve breast cancer patients without any therapeutic interposition classified from stage I to stage IV according to the National Comprehensive Cancer Network (NCCN) clinical practice guidelines in oncology. ${ }^{14}$ Breast cancer patients with previous chemotherapy or radiotherapy treatment were excluded. Tumor estrogen/progesterone receptor (ER/PR) status and HER2 status were determined by immunohistochemistry (IHC). Demographic data, clinicopathological characteristics, and reproductive history at the time of presentation were collected and evaluated. Such data are routinely recorded on the patient's file sheet questionnaire by the examining physician including age, marital status in addition to family history of breast cancer. Data on tumor size and nodal status were obtained by examination of the tissue biopsies. Abdominal ultrasound and chest $X$ rays, CT chest and abdomen and bone scan were carried out to exclude metastases. The control criteria included age matched women with no signs or symptoms of breast cancer. Women with chronic infections, autoimmune diseases, or who receive immunosuppressive treatment were not included in the control group.

\section{Peripheral Blood Mononuclear Cell (PBMCs) Isolation}

Five milliliters of blood were withdrawn from each subject under complete aseptic conditions into heparinized tubes. Peripheral blood mononuclear cells (PBMCs) were isolated based on density-gradient centrifugation using FicollPaque (Histopaque-1077, Sigma-Aldrich). ${ }^{15}$ 
Analysis of B-regs surface markers, induction and detection of intracellular cytokine (IL-10) by Flow cytometry

PBMCs were re-suspend in $1 \mathrm{~mL}$ of warm RPMI media, add $2 \mu \mathrm{l}$ of cell stimulation cocktail (500X); phorbol 12-myristate 13-acetate (PMA) (100 ng/mL, Sigma-Aldrich) and ionomycin $(1 \mu \mathrm{g} / \mathrm{mL}$, Sigma-Aldrich). One microliter of Brefeldin A (1000X) (BioLegand, USA), a protein transport inhibitor, was added to block cytokine secretion at the Golgi. The cells were then washed with PBS, and Fc receptors were blocked using $10 \mu \mathrm{L}$ of human serum and incubated for $15 \mathrm{~min}$ at room temperature in a dark place. After incubation, an extracellular staining was performed by incubating the cells with fluorescently labeled antibodies (Table 1) for 30 minutes at room temperature in a dark place. Cells were then fixed and permeabilized using Flow Cytometry Fixation / Permeabilization Buffer I (1X, R\&D systems, Bio-
Techne, USA), stained with anti-IL-10 (Table 1) and the mixture incubated for 30-45 minutes at 2-8 ${ }^{\circ} \mathrm{C}$. Cells were then washed and resuspended in PBS, and measured by FACS Caliber (Becton Dickinson, USA) flow cytometer. ${ }^{16}$ An isotype-matched negative control was used for each sample. Analysis was performed using FlowJo (Version 10) software.

\section{Statistical analysis}

All statistical analyses were carried out using SPSS for Windows version 17 (SPSS, Chicago, IL, USA). Graphs were created in Prism 7 (GraphPad Software Inc., San Diego, CA, USA). Quantitative data were expressed as mean \pm standard deviation. The statistical significance was assessed with unpaired two-tailed Student's t test and one-way ANOVA test. Twosided $p$-values were calculated; the differences were considered statistically significant at $P<$ 0.05 .

Table 1. List of used antibodies

\begin{tabular}{lccc}
\hline Antigenic Target & Fluorochrome & Clone & Manufacturer \\
\hline CD19 & PerCP & 4G7-2E3 & R\&D systems \\
CD24 & APC & ML5 & R\&D systems \\
CD27 & FITC & LG.7F9 & e-Bioscience \\
IL-10 & PE & REA1008 & Miltenyi Biotec \\
\hline
\end{tabular}

\section{Results}

\section{Clinical and pathological data of patients}

Table 2 shows that 33 (82.5\%) and 7 (17.5\%) patients were diagnosed as invasive ductal carcinoma (IDC), and invasive lobular carcinoma (ILC), respectively. BC laterality was not associated with human histology $(P=0.7931)$. According to the NCCN guidelines in oncology of 2018 ; 1 of $40(2.5 \%)$ was in stage I, and 37 of 40 $(92.5 \%)$ were in stage II, 1 of $40(2.5 \%)$ was in stage III, and 1 of $40(2.5 \%)$ in stage IV. The estrogen receptor positive $(E R+) /$ progesterone receptor positive $(\mathrm{PR}+)$ phenotype was recorded in $75 \%(30 / 40)$ of the studied population while the ER-/PR- variant were displayed in $17.5 \%$ (7/40) of them. BC laterality was not associated with ER/PR or Her-2 expression ( $P>0.05$ for both). Also, BC laterality was not associated with TNM or TNM stage grouping ( $P>0.05)$. Tumor metastasis in all cases was undetermined. The risk factors for breast cancer are shown in Table 3.

Analysis of regulatory $B$ cells in the studied groups

Frequency of $\mathrm{CD}_{19} \mathrm{~B}^{+}$cells in peripheral blood of patients and controls

The mean percentage of $\mathrm{CD}_{1} 9^{+} \mathrm{B}$ cells in $\mathrm{BC}$ patients represented $13.46 \%$ of the cells in patients' lymphocyte gate compared to control individuals with mean percentage of $16.48 \%$ (Figure 1: A, B1 \& B2). There was a significant decrease in $\mathrm{CD}_{19}{ }^{+} \mathrm{B}$ cells percentage in patients compared to controls $(P<0.0001)$.

Frequency of $C D 19^{+} I L 10^{+} B$ cells (B-regs) in peripheral blood of patients and controls

The frequency of $B 10$ cells (CD19 ${ }^{+} \mathrm{IL} 10^{+} \mathrm{B}$ cells) in $B C$ patients was $4.82 \%$ of $B$ cells which was significantly higher than B10 cells in control individuals $(P<0.0001)$ with a percentage of $1.05 \%$ of B cells (Figure 1: C1, C2). 
Frequency of $C D 19^{+} C D 24^{h i} C D 27^{+}$, and $C D 19^{+} C D 24^{h i} C D 27^{+} I L 10^{+}$B-regs phenotypes in peripheral blood of patients and controls

As B-regs have different phenotypes, we analyzed cell surface markers as CD24, and CD27 after in vitro stimulation to identify different phenotypes of B-regs. In BC patients, $\mathrm{CD} 19^{+} \mathrm{CD} 24^{\text {hi }} \mathrm{CD} 27^{+} \mathrm{B}$ cells composed $13.82 \%$ of $B$ cells which was significantly lower compared to control individuals $(P<0.0001)$, which composed $19.02 \%$ of B cells (Figure 1, D1\& D2). Also, it was found that $\mathrm{CD} 19^{+} \mathrm{CD} 24^{\text {hi }} \mathrm{CD} 27^{+} \mathrm{IL} 10^{+} \mathrm{B}$ cells composed $1.75 \%$ of total $B$ cells in $B C$ patients, significantly higher than these detected in in control individuals $(P<0.0001)$ with a percentage of $0.64 \%$ of total B cells (Figure 1, E1 \& E2).

Table 2. Clinical and pathological data of patients.

\begin{tabular}{|c|c|c|c|c|c|c|c|}
\hline \multirow[t]{2}{*}{ Characteristic } & \multirow{2}{*}{$\begin{array}{c}\text { Total } \\
\text { BCs } \\
N\end{array}$} & \multicolumn{2}{|c|}{ Left BCs } & \multicolumn{2}{|c|}{ Right BCs } & \multirow[t]{2}{*}{$P$-value } & \multirow[t]{2}{*}{ LRR } \\
\hline & & $N$ & $\%$ & $N$ & $\%$ & & \\
\hline \multicolumn{8}{|l|}{ *Histology: $(n=40)$} \\
\hline Ductal & 33 & 18 & 54.5 & 15 & 45.56 & \multirow{3}{*}{ NS } & 1.2 \\
\hline Lobular & 7 & 5 & 71.4 & 2 & 28.6 & & 2.5 \\
\hline Mixed ductal and lobular & 0 & 0 & 0.0 & 0 & 0.0 & & 0 \\
\hline \multicolumn{8}{|l|}{$*$ Grade: $(n=40)$} \\
\hline 1 & 1 & 1 & 100 & 0 & 0.0 & \multirow{4}{*}{ NS } & _ \\
\hline 2 & 37 & 20 & 54.05 & 17 & 45.95 & & $1 . \overline{18}$ \\
\hline 3 & 1 & 1 & 100 & 0 & 0.0 & & - \\
\hline 4 & 1 & 1 & 100 & 0 & 0.0 & & - \\
\hline \multicolumn{8}{|l|}{ *Hormonal Receptors: } \\
\hline $\mathrm{ER}+/ \mathrm{PR}+$ & 30 & 17 & 56.67 & 13 & 43.33 & \multirow{4}{*}{ NS } & 1.31 \\
\hline$E R+/ P R-$ & 2 & 1 & 50 & 1 & 50 & & 1 \\
\hline ER-/ PR+ & 1 & 1 & 100 & 0 & 0 & & - \\
\hline ER-/ PR- & 7 & 4 & 57.14 & 3 & 42.86 & & 1.33 \\
\hline \multicolumn{8}{|l|}{ *HER2: $(n=21)$} \\
\hline Non over expressed $(0-2+)$ & 19 & 10 & 52.6 & 9 & 47.4 & \multirow{2}{*}{ NS } & 1.1 \\
\hline Over expressed (3+) & 2 & 2 & 100 & 0 & 0.0 & & \\
\hline \multicolumn{8}{|l|}{ *T stage: $(n=40)$} \\
\hline 1 & 6 & 4 & 66.67 & 2 & 33.33 & \multirow{4}{*}{ NS } & 2 \\
\hline 2 & 21 & 11 & 52.38 & 10 & 47.62 & & 1.1 \\
\hline 3 & 8 & 4 & 50 & 4 & 50 & & 1 \\
\hline 4 & 5 & 4 & 80 & 1 & 20 & & 4 \\
\hline \multicolumn{8}{|l|}{${ }^{*} N$ stage: $(n=40)$} \\
\hline 1 & 20 & 11 & 55 & 9 & 45 & \multirow{4}{*}{ NS } & 1.22 \\
\hline 2 & 12 & 7 & 58.3 & 5 & 41.67 & & 1.4 \\
\hline 3 & 8 & 5 & 62.5 & 3 & 37.5 & & 1.67 \\
\hline Mo stage & 40 & - & - & - & - & & - \\
\hline \multicolumn{8}{|l|}{ *TNM stage group: } \\
\hline II & 17 & 10 & 58.82 & 7 & 41.18 & \multirow{2}{*}{ NS } & 1.43 \\
\hline III & 23 & 13 & 56.5 & 10 & 43.5 & & 1.3 \\
\hline
\end{tabular}

ER: estrogen receptor, PR: progesterone receptor, HER2: human epidermal growth factor receptor, TNM: tumor, node, and metastasis., $P>0.05$ is not significant (NS). 
Table 3. Breast cancer associated risk factors.

\begin{tabular}{|c|c|c|c|c|c|c|}
\hline \multirow{2}{*}{ Risk factor } & \multicolumn{2}{|c|}{ Cases $(N=40)$} & \multicolumn{2}{|c|}{ Controls $(N=10)$} & \multirow{2}{*}{ Odds ratio $(95 \% \mathrm{Cl})$} & \multirow{2}{*}{$\begin{array}{c}P \text { - } \\
\text { value }\end{array}$} \\
\hline & No. & $\%$ & No. & $\%$ & & \\
\hline Age of marriage: & $(N=37)$ & & $(\mathrm{N}=9)$ & & \multirow{3}{*}{$\begin{array}{c}2.353 \\
(0.5754-9.437)\end{array}$} & \multirow{3}{*}{ NS } \\
\hline * more than 21 years & 20 & 54.05 & 3 & 33.33 & & \\
\hline * Up to 21 years & 17 & 45.95 & 6 & 66.67 & & \\
\hline $\begin{array}{l}\text { Age of } 1^{\text {st }} \text { pregnancy } \\
\text { (years): }\end{array}$ & $(N=33)$ & & $(\mathrm{N}=8)$ & & \multirow{3}{*}{$\begin{array}{c}1.228 \\
(0.2426-5.226)\end{array}$} & \multirow{3}{*}{ NS } \\
\hline$* \geq 25$ years & 14 & 42.42 & 3 & 37.5 & & \\
\hline$*<25$ years & 19 & 57.58 & 5 & 62.5 & & \\
\hline $\begin{array}{l}\text { Age at last childbirth } \\
\text { (years): }\end{array}$ & $(N=33)$ & & $(\mathrm{N}=8)$ & & \multirow{3}{*}{$\begin{array}{c}1.304 \\
(0.236-7.18)\end{array}$} & \multirow{3}{*}{ NS } \\
\hline *Up to 28 & 10 & 30.3 & 2 & 25 & & \\
\hline *More than 28 & 23 & 69.7 & 6 & 75 & & \\
\hline $\begin{array}{l}\text { Total breastfeeding } \\
\text { duration: }\end{array}$ & $(N=33)$ & & $(\mathrm{N}=8)$ & & \multirow{3}{*}{$\begin{array}{c}1.885 \\
(0.2124-23.96)\end{array}$} & \multirow{3}{*}{ NS } \\
\hline *Up to six months & 7 & 21.21 & 1 & 12.5 & & \\
\hline *More than six months & 26 & 78.79 & 7 & 87.5 & & \\
\hline History of abortions: & $(N=37)$ & & $(\mathrm{N}=9)$ & & \multirow{3}{*}{$\begin{array}{c}1.481 \\
(0.3068-7.88)\end{array}$} & \multirow{3}{*}{ NS } \\
\hline *Yes & 11 & 29.73 & 2 & 22.22 & & \\
\hline *No & 26 & 70.27 & 7 & 77.78 & & \\
\hline $\begin{array}{l}\text { History of oral } \\
\text { contraceptive pills: }\end{array}$ & $(N=37)$ & & $(N=9)$ & & \multirow{3}{*}{$\begin{array}{c}2.667 \\
(0.5814-13.79)\end{array}$} & \multirow{3}{*}{ NS } \\
\hline *Yes & 16 & 43.24 & 2 & 22.22 & & \\
\hline$*$ No & 21 & 56.76 & 7 & 77.78 & & \\
\hline $\begin{array}{l}\text { Age at menopause } \\
\text { (years): }\end{array}$ & $(N=22)$ & & $(N=3)$ & & \multirow{3}{*}{$\begin{array}{c}0.875 \\
(0.05427-8.503)\end{array}$} & \multirow{3}{*}{ NS } \\
\hline *More than 50 & 14 & 63.64 & 2 & 66.67 & & \\
\hline *Up to 50 & 8 & 36.36 & 1 & 33.33 & & \\
\hline \multicolumn{6}{|l|}{$\begin{array}{l}\text { Family history of breast } \\
\text { cancer: }\end{array}$} & \multirow{3}{*}{ NS } \\
\hline$*$ Yes & 21 & 52.5 & 2 & 20 & 4.421 & \\
\hline$*$ No & 19 & 47.5 & 8 & 80 & $(0.8211-22.12)$ & \\
\hline
\end{tabular}

$\mathrm{N}$ : number, \%: percentage, $\mathrm{Cl}$ : confidence interval. $P>0.05$ is not significant (NS). 

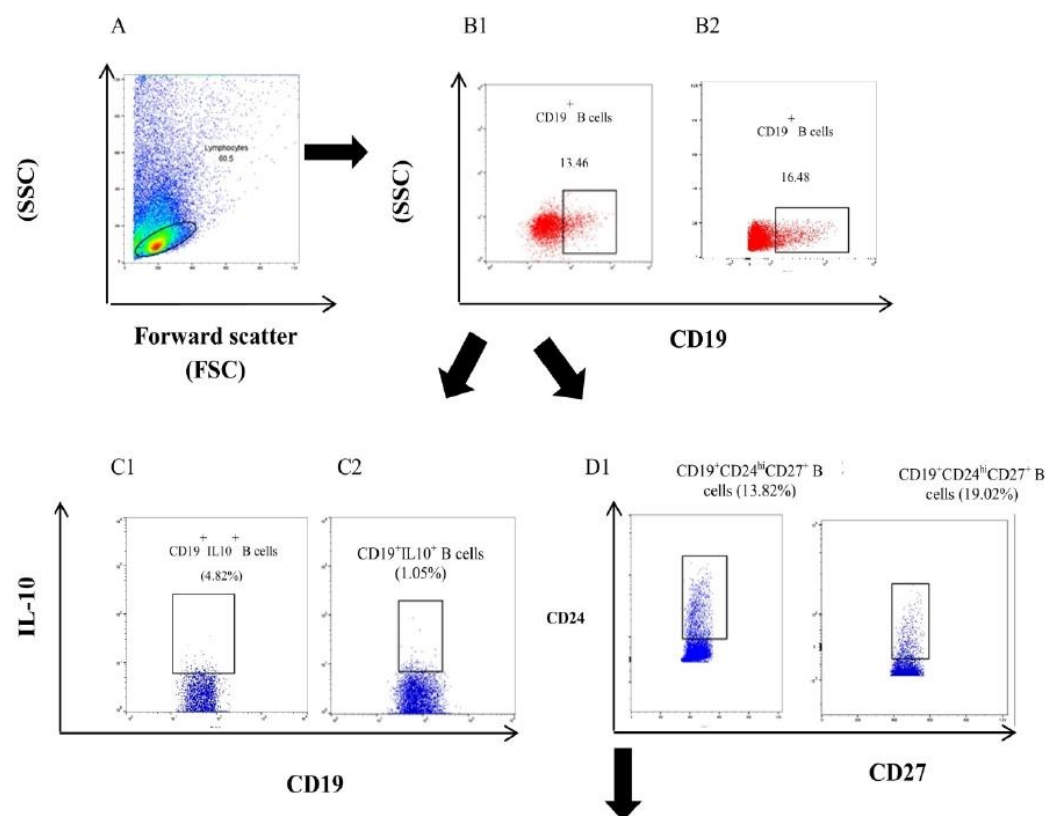

E1

E2

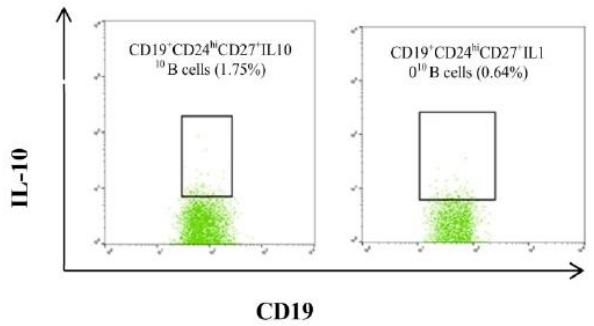

Figure 1. Representative gating strategy for identifying B-cell subsets. (A) lymphocytes are gated on the forward scatter (FSC)/side scatter (SSC) dot plot of PBMCs population. (B) CD19 ${ }^{+} \mathrm{B}$ cells a frequency in PBMCs from $B C$ patients and controls; (B1) represents CD19 ${ }^{+}$cells were gated on side scatter and CD19 dot plot in BC patient. (B2) $C D 19^{+}$cells were gated on side scatter and CD19 dot plot in healthy control. (C) Frequencies of $\mathrm{CD}_{10}{ }^{+} \mathrm{IL} 10^{+} \mathrm{B}$ cells in healthy individuals and $\mathrm{BC}$ patients after in vitro stimulation; (C1) Dot plotting represents $B 10$ cells frequency in $B C$ patient, (C2) Dot plotting represents frequency of B10 cells in healthy individual. (D) Frequencies of $\mathrm{CD} 19^{+} \mathrm{CD} 24^{\mathrm{hi}} \mathrm{CD} 27^{+} \mathrm{B}$-regs in healthy individuals and $\mathrm{BC}$ patients after in vitro stimulation; (D1) Dot plotting represents percentage of $C D 19^{+} C D 24^{\text {hi }} C D 27^{+} B$ cells in total $C D 19^{+} B$ cells from $B C$ patient, (D2) Dot plotting represents percentage of $\mathrm{CD} 19^{+} \mathrm{CD} 24^{\text {hi }} \mathrm{CD} 27^{+} \mathrm{B}$ cells in total $\mathrm{CD} 19^{+} \mathrm{B}$ cells in healthy control. $(\mathrm{E})$ : Frequencies of $\mathrm{CD} 19^{+} \mathrm{CD} 24^{\mathrm{hi}} \mathrm{CD} 27^{+} \mathrm{IL} 10^{+} \mathrm{B}$-regs phenotype in the blood of $\mathrm{BC}$ patients and healthy individuals after in vitro stimulation; (E1) Dot plotting represents percentage of $C D 19^{+} C D 24^{\text {hi }} C D 27^{+} I L 10^{+} B$ cells detected in $B C$ patient, (E2) Dot plotting represents percentage of $C D 19^{+} C D 24^{\text {hi }} C D 27^{+} I L 10^{+} B$ cells detected in healthy control.

The relation between circulating $B$-regs phenotypes and different clinical features of $B C$ patients

The percentage of $\mathrm{CD}_{19}{ }^{+} \mathrm{IL} 10^{+}$(B10) B cells phenotype was significantly associated with the HER-2 expression levels, and $\mathrm{T}$, and $\mathrm{N}$ stages (Figure 2: A, B, C). However, there was no significance association between this phenotype and other clinical features of BC patients $(P>$ 0.05 for all). The $\mathrm{CD} 19^{+} \mathrm{CD} 24^{\text {hi }} \mathrm{CD} 27^{+}$and CD $19^{+} \mathrm{CD} 24{ }^{\text {hi }} \mathrm{CD} 27^{+}$IL10 ${ }^{+}$B cells phenotypes were not significantly associated with any of the clinical features of BC patients $(P>0.05)$ as shown in Table 4. The ER/PR expression levels were not significantly associated with regulatory B cells phenotypes (Figure 3: A, B, C). 


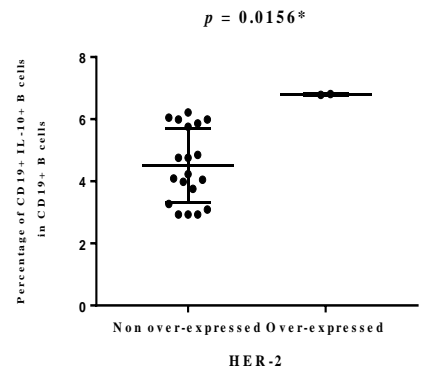

(A)

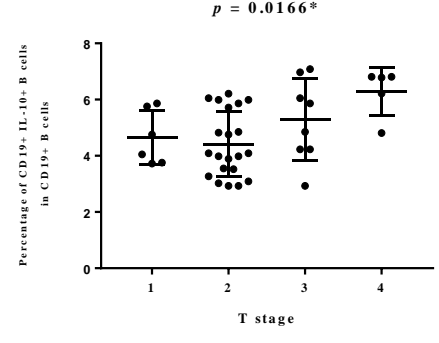

(B)

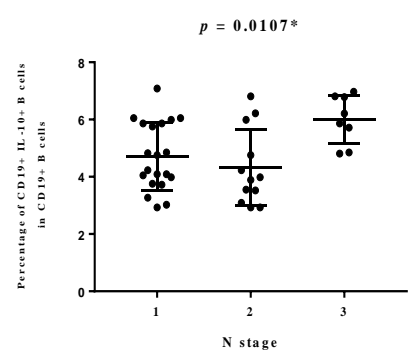

(C)

Figure 2. (A) Percentage of $C D 19^{+} I L 10^{+}$(B10) cells in $C D 19^{+} B$ cells in $B C$ patients with different HER-2 expression levels. (B) Percentage of $\mathrm{CD}^{1} 9^{+} \mathrm{IL} 10^{+}$(B10) cells in $\mathrm{CD} 19^{+} \mathrm{B}$ cells in $\mathrm{BC}$ patients at different T stages. (C) Percentage of $\mathrm{CD} 19^{+} \mathrm{IL} 10^{+}$(B10) cells in $\mathrm{CD} 19^{+} \mathrm{B}$ cells in $\mathrm{BC}$ patients at different $\mathrm{N}$ stages. Data are expressed as mean $\pm \mathrm{SD}$.

Table 4. Association between circulating B-regs phenotypes and clinico-pathological characteristics of $\mathrm{BC}$ patients.

\begin{tabular}{|c|c|c|c|c|c|c|c|}
\hline Characteristics & $\begin{array}{l}\text { Number } \\
\text { of cases }\end{array}$ & $\begin{array}{l}\mathrm{CD}^{+} 9^{+} \mathrm{IL} 10^{+} \\
\text {(B10) cells }\end{array}$ & $\begin{array}{c}{ }^{*} P \text { - } \\
\text { value }\end{array}$ & $\begin{array}{c}\mathrm{CD}_{19} 9^{+} \mathrm{CD} 2^{\text {hi }} \mathrm{CD} 27^{+} \\
\text {B cells }\end{array}$ & $\begin{array}{c}P- \\
\text { value }\end{array}$ & $\begin{array}{l}\mathrm{CD} 19^{+} \mathrm{CD} 2^{\text {hi }} \mathrm{CD} 2 \\
7^{+} \mathrm{IL} 10^{+} B \text { cells }\end{array}$ & $\begin{array}{c}P- \\
\text { value }\end{array}$ \\
\hline \multicolumn{8}{|l|}{ *Age: } \\
\hline $25-44$ & 11 & $5.215 \pm 0.39$ & \multirow{3}{*}{ NS } & $13.95 \pm 0.45$ & \multirow{3}{*}{ NS } & $1.634 \pm 0.19$ & \multirow{3}{*}{ NS } \\
\hline $45-64$ & 23 & $4.632 \pm 0.26$ & & $13.53 \pm 0.23$ & & $1.779 \pm 0.15$ & \\
\hline$\geq 65$ & 6 & $5.038 \pm 0.64$ & & $12.69 \pm 0.33$ & & $2.53 \pm 0.30$ & \\
\hline \multicolumn{8}{|l|}{ *Histology: } \\
\hline Ductal & 33 & $4.747 \pm 0.23$ & \multirow{2}{*}{ NS } & $13.43 \pm 0.22$ & \multirow{2}{*}{ NS } & $1.864 \pm 0.13$ & \multirow{2}{*}{ NS } \\
\hline Lobular & 7 & $5.353 \pm 0.43$ & & $13.92 \pm 0.42$ & & $1.557 \pm 0.19$ & \\
\hline \multicolumn{8}{|l|}{ *Grade: } \\
\hline 1 & 1 & $4.05 \pm 0.0$ & \multirow{4}{*}{ NS } & $14.55 \pm 0.0$ & \multirow{4}{*}{ NS } & $1.93 \pm 0.0$ & \multirow{4}{*}{ NS } \\
\hline 2 & 37 & $4.77 \pm 0.21$ & & $13.49 \pm 0.21$ & & $1.826 \pm 0.12$ & \\
\hline 3 & 1 & $6.81 \pm 0.0$ & & $13.25 \pm 0.0$ & & $1.47 \pm 0.0$ & \\
\hline 4 & 1 & $6.78 \pm 0.0$ & & $13.87 \pm 0.0$ & & $1.43 \pm 0.0$ & \\
\hline \multicolumn{8}{|c|}{ *Hormonal Receptors: } \\
\hline $\mathrm{ER}+/ \mathrm{PR}+$ & 30 & $6.71 \pm 0.26$ & \multirow{4}{*}{ NS } & $13.25 \pm 0.19$ & \multirow{4}{*}{ NS } & $1.79 \pm 0.13$ & \multirow{4}{*}{ NS } \\
\hline $\mathrm{ER}+/ \mathrm{PR}-$ & 2 & $4.33 \pm 0.44$ & & $13.53 \pm 0.20$ & & $2.17 \pm 0.65$ & \\
\hline ER-/ PR+ & 1 & $4.82 \pm 0.00$ & & $15.03 \pm 0.00$ & & $2.24 \pm 0.00$ & \\
\hline ER-/ PR- & 7 & $4.53 \pm 0.40$ & & $14.45 \pm 0.47$ & & $1.74 \pm 0.26$ & \\
\hline \multicolumn{8}{|l|}{ *HER-2: $(n=21)$} \\
\hline $\begin{array}{l}\text { Non over expr } \\
(0-2+)\end{array}$ & & $4.5 \pm 0.27$ & \multirow{2}{*}{0.0156} & $13.82 \pm 0.31$ & \multirow{2}{*}{ NS } & $1.691 \pm 0.17$ & \multirow{2}{*}{ NS } \\
\hline $\begin{array}{l}(U-\angle+) \\
\text { Over expressed }\end{array}$ & $3+)$ & $6.795 \pm 0.2$ & & $13.56 \pm 0.31$ & & $1.45 \pm 0.02$ & \\
\hline \multicolumn{8}{|c|}{ *T stage: } \\
\hline 1 & 6 & $4.652 \pm 0.97$ & \multirow{4}{*}{0.0166} & $13.83 \pm 0.74$ & \multirow{4}{*}{ NS } & $1.548 \pm 0.22$ & \multirow{4}{*}{ NS } \\
\hline 2 & 21 & $4.409 \pm 0.25$ & & $13.64 \pm 0.24$ & & $1.892 \pm 0.17$ & \\
\hline 3 & 8 & $5.275 \pm 0.52$ & & $12.94 \pm 0.34$ & & $2.006 \pm 0.27$ & \\
\hline 4 & 5 & $6.286 \pm 0.39$ & & $13.57 \pm 0.13$ & & $1.464 \pm 0.36$ & \\
\hline \multicolumn{8}{|l|}{ *N stage: } \\
\hline 1 & 20 & $4.711 \pm 0.26$ & \multirow{3}{*}{0.0107} & $13.93 \pm 0.28$ & \multirow{3}{*}{ NS } & $1.827 \pm 0.16$ & \multirow{3}{*}{ NS } \\
\hline 2 & 12 & $4.325 \pm 0.39$ & & $13.07 \pm 0.34$ & & $1.803 \pm 0.23$ & \\
\hline 3 & 8 & $6.001 \pm 0.30$ & & $13.17 \pm 0.32$ & & $1.779 \pm 0.20$ & \\
\hline \multicolumn{8}{|c|}{ *TNM stage group: } \\
\hline$I+I I$ & 17 & $4.628 \pm 0.31$ & NS & $13.58 \pm 0.34$ & NS & $1.756 \pm 0.19$ & NS \\
\hline III & 23 & $5.02 \pm 0.27$ & NS & $13.47 \pm 0.23$ & NS & $1.85 \pm 0.13$ & INS \\
\hline
\end{tabular}

ER: estrogen receptor, PR: progesterone receptor, HER2: human epidermal growth factor receptor, TNM: tumor, node, and metastasis. ${ }^{*} P>0.05$ is not significant (NS). 


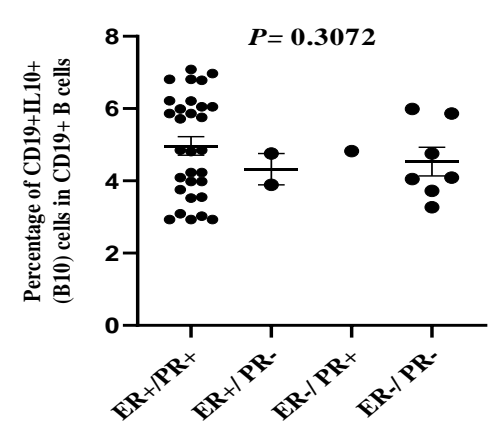

(A)

(B)

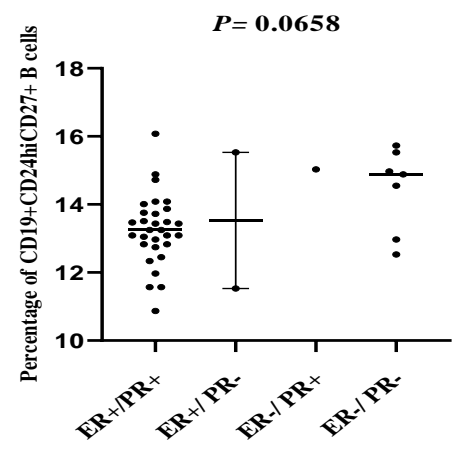

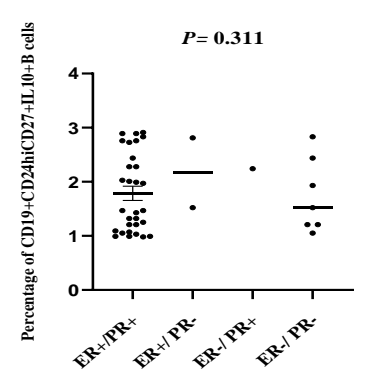

(C)

3. (A) Percentage of $C D 19+L 10^{+}(B 10)$ cells in $C D 19^{+} B$ cells in $B C$ patients with different $E R / P R$ levels. (B) Percentage of $C D 19^{+} C D 24^{\text {hi }} C D 27^{+}$B-regs in $B C$ patients with different ER/PR levels. (C) Percentage of $C D 19^{+} C D 24^{\text {hi }} \mathrm{CD} 27^{+}$IL $10^{+} B$ cells in $B C$ patients with different ER/PR levels. Data are expressed as mean $\pm S D$.

\section{Discussion}

Breast cancer is ranked within the most common female neoplasms worldwide, which is increasing particularly in developing countries where the majority of cases are diagnosed in late stages. The peak frequency of breast cancer increased with age until menopause, thereafter it started to decline. The mean age of BC patients in this study was $(51.53 \pm 1.95)$ years; this is in accordance with Gabr et al. (2016) who reported that two third of the patients were between their forties and sixties, displaying a noticeable decline after the age of 60 years. ${ }^{17}$ World Health Organization (WHO) estimates revealed that half of the cancers in the Eastern Mediterranean Region (EMR) occur before the age of 55 years. ${ }^{18}$

In this study BC involves left side (LS) more than right side (RS) with LS-to-RS ratio (LRR) of 1.35. LS breast cancer is more predominant in (55-64) age group with $20 \%$ from total cases. The leading tumor type was IDC; $82.5 \%$ followed by ILC; $17.5 \%$. Makar, (2019) reported that the most common histopathological type was IDC and approximately one third of the patients had grade III tumor. ${ }^{19}$ According to the NCCN guidelines in oncology, 2018; 92.5\% were in stage II. Similar results were reported by a previous study in Egypt; Gihan et al. (2019). They found that most BC cases were either stage II (37\%) or stage III (44.6\%) while $4.2 \%$ and $14.2 \%$ of cases in Stage I and IV, respectively. ${ }^{20}$ Surveys from other developing countries reported high proportions of advanced stages at presentation. ${ }^{21}$ Such finding could be explained mainly by the lack of early detection programs which results in a high proportion of women presented with late-stage disease. Furthermore, absence of adequate diagnosis and treatment facilities could lead to the same observation.

Patients with hormone receptor-expressed tumors, such as ER+ and/or PR+ will gain effective endocrine therapy which is usually offered after surgery and radiotherapy for BC. It can reduce the risk of deaths due to breast cancer and recurrence in those patients. Hormone receptor status and HER2 status are of critical interest in determining the prognosis of breast cancer patients. Their status is routinely assessed by $\mathrm{IHC}^{22}$ While the ER+/PR+ phenotype was recorded in $75 \%$ of our studied patients, the ER-/PR- variant $17.5 \%$, the ER+/PR$5 \%$ and the ER-/PR+ 2.5\%. Gabr et al., (2016) reported that the ER+/PR+ phenotype was recorded in $40.6 \%$ of the studied population, the ER-/PR- variant displayed in $30.4 \%$, and $\mathrm{ER} / \mathrm{PR}$ undetermined in $20 \%{ }^{17}$ HER2 is a growth-promoting protein on the outside of all breast cells. Breast cancer cells with higherthan-normal levels of HER-2 are called HER-2positive. These cancers tend to grow and spread faster than other breast cancers, but are much more likely to respond to treatment with drugs that target the HER2 protein. ${ }^{23}$ Among our Egyptian BC patients only $9.52 \%$ were HER-2positive. $B C$ laterality was not associated with expression of ER/PR or HER-2; however their expression was more predominant in left-sided tumors. Also, BC laterality was neither associated with TNM classification nor TNM stage grouping. 
Recently, research have adapted a new wave to identify the role of B-regs which had immunosuppressive functions in carcinogenesis. B-regs, an important B cell subset producing IL10, had been shown to contribute to autoimmune diseases, cancers, and chronic infections. ${ }^{24}$

This study found that that the proportion of total B cells among PBMCs was significantly higher in the controls than in $B C$ patients with a mean percentage of $16.48 \%$, and $13.46 \%$, respectively. Tsuda et al. (2018) found differences in B-cell differentiation between BC patients and healthy donors. Low-B patients had the same proportion of $B$ cells as the control group, while the proportion of $B$ cells in high-B patients was higher than in the controls. Their statistical analysis revealed that B-cell increase to be due to the significantly increased proliferation or survival of memory $B$ cells in the high- $B$ group compared with the other groups. The increase in $B$ cell in $B C$ patients and the increase in memory $B$ cells are indicative of previous humeral immunity activation in $B C$ patients, although the cause of this and its implications for cancer progression cannot be determined. ${ }^{25}$ This variation may be attributed to the difference between studied patient populations, the difference between the number of investigated specimens, also, the stage and subtype of $B$ cells were not considered in that study. In future studies, it will be necessary to conduct more detailed analyses on a larger number of clinical samples.

In this study, the frequency of circulating Bregs $\left(\mathrm{CD} 19^{+} \mathrm{IL} 10^{+} \mathrm{B}\right.$ cells) was increased in $\mathrm{BC}$ patients than in controls with a mean percentage of $4.85 \%$, and $1.16 \%$, respectively. Although there are limited number of studies about B-regs frequency in $B C$, but there are studies concerning the role of B-regs in other types of cancers, which agreed with our results. In a study about lung cancer, it was found that the frequency of $\mathrm{CD} 19^{+} \mathrm{IL} 10^{+} \mathrm{B}$ cells in lung cancer patients was significantly higher than in control individuals. ${ }^{26}$ Such finding may indicate that B-regs are associated with immune evasion in BC. Another study in Egypt found that the frequency of B-regs was significantly higher in hepatitis $C$ virus patients with hepatocellular carcinoma compared to the controls. ${ }^{27} \mathrm{~A}$ recent study on cervical carcinoma found that B-reg cells in cervical cancer patients were significantly increased, which was closely related to disease progression. ${ }^{28}$

The proportion of $\mathrm{CD} 19^{+} \mathrm{CD} 24^{\mathrm{hi}} \mathrm{CD} 27^{+}$B-regs phenotype was significantly lower in $\mathrm{BC}$ patients than in the controls $(P<0.0001)$. This finding was close to that reported by another study which found significant decrease in $\mathrm{CD} 24^{\mathrm{hi}} \mathrm{CD} 27^{+}$ $B$ cells in metastatic lymph node (MLNs) in BC, and explained the relation between this B-regs phenotype and lymph node metastasis. ${ }^{29}$ Another study on gastric cancer confirmed that the $\mathrm{CD}_{19} 9^{+} \mathrm{CD} 24^{\mathrm{hi}} \mathrm{CD} 27^{+}$B cell population contained cells that suppressed the proliferation of $\mathrm{CD}^{+} \mathrm{T}$ cells and inhibited the secretion of IFN-gamma by autologous $\mathrm{CD} 4^{+} \mathrm{T}$ cells, indicating that the $\mathrm{CD} 19^{+} \mathrm{CD} 24^{\mathrm{hi}} \mathrm{CD} 27^{+} \mathrm{B}$ cell population contained B-regs. However, the frequency of B-regs was not high even in the $\mathrm{CD} 19^{+} \mathrm{CD} 24^{\mathrm{hi}} \mathrm{CD} 27^{+} \mathrm{B}$ cell subset, and B-regs were also contained in other populations, indicating that this phenotyping strategy could not uniquely identify B-regs. ${ }^{30}$

However, the proportion of $\mathrm{CD} 19^{+} \mathrm{CD} 24^{\text {hi }} \mathrm{CD} 27^{+} \mathrm{IL} 10^{+}$B-regs phenotype was significantly higher in $B C$ patients than in controls $(P<0.0001)$. The percentage of $\mathrm{CD} 19^{+} \mathrm{IL} 10^{+} \mathrm{B}$ cells phenotype was significantly associated with the HER-2 expression levels, T, and $\mathrm{N}$ stages of BC. However, there was no significant association between this phenotype and other clinical features of $B C$ patients like age, $B C$ histology, $B C$ grade, ER/PR expression levels. For $\mathrm{CD}_{19} 9^{+} \mathrm{CD} 24^{\text {hi }} \mathrm{CD} 27^{+}$and $\mathrm{CD} 19^{+} \mathrm{CD} 24$ ${ }^{\text {hi }} \mathrm{CD} 27^{+} \mathrm{IL} 10^{+} \mathrm{B}$ cells phenotype, there were not significantly associated with any of clinicpathological features of $B C$ patients. This may indicate that $\mathrm{B}$-regs of memory $\mathrm{B}$ cells origin are not related to clinical features of $B C$ patients. Murakami et al. (2019) found that increased numbers of B-regs were significantly correlated with poor prognosis in gastric cancer patients although there was no significant correlation between the frequency of B-regs and clinicopathologic characteristics. ${ }^{30}$

In conclusion, high percentage of B-regs phenotypes ${\mathrm{CD} 19^{+} \mathrm{IL} 10^{+} \text {and }}^{+}$ $\mathrm{CD} 19^{+} \mathrm{CD} 24^{\mathrm{hi}} \mathrm{CD} 27^{+} \mathrm{IL} 10^{+}$in $\mathrm{BC}$ patients may indicate a possible role in immune-suppression during the development of $\mathrm{BC}$. The percentage of $\mathrm{CD} 19^{+} \mathrm{IL} 10^{+} \quad \mathrm{B}$ cells phenotype was 
significantly associated with the HER-2 expression levels, $\mathrm{T}$ and $\mathrm{N}$ stages of $\mathrm{BC}$.

\section{Acknowledgments}

We acknowledge the Medical Research Center, Faculty of Medicine, Assiut University for providing the necessary laboratory equipment for carrying out the experiments.

\section{Author Contributions}

All authors made a significant contribution to this work, whether that is in the conception, study design, acquisition of data, analysis and interpretation, or in drafting, revising or reviewing the article and gave final approval of the version to be published.

\section{Data Availability}

The datasets used and/or analyzed during the current study are available from the corresponding author on reasonable request.

\section{Declaration of Conflicting Interests}

The author(s) declared no potential conflicts of interest with respect to the research, authorship, and/or publication of this article.

\section{Funding}

This research was funded by the Grant Office, Faculty of Medicine, Assiut University, (Grant number 20160629-033).

\section{Ethical approval}

The study protocol was reviewed and approved by the Ethical Committee of the Faculty of Medicine, Assiut University (Approval number 17200384).

\section{Informed consent}

Informed written consent was obtained from all participants before enrolment.

\section{References}

1. Ibrahim A, Khaled HM, Mikhail NN, et al (2014) Cancer Incidence in Egypt: Results of the National Population-Based Cancer Registry Program. Journal of Cancer Epidemiology 2014; 437971:18.

2. Siegel RL, Miller KD, Jemal A. et al (2017) Cancer Statistics, A Cancer Journal for Clinicians; 67:7-30.

3. Mahmoud MA, Amin MA. (2009) Evaluation of donut mammoplasty in early breast cancer near to nipple-areola complex. EJ of Surg, 39:11-22.
4. Lundy SK. Killer B et al (2014) lymphocytes: the evidence and the potential. Inflamm Res; 58 7:345357.

5. Akshay JP, Alex R, Mark T, Drayson1, et al (2020) The role of $B$ lymphocytes in the immuno-biology of non-small-cell lung cancer. Cancer Immunology, Immunotherapy; 69:325-342.

6. Kahn JA. (2009) HPV vaccination for the prevention of cervical intraepithelial neoplasia. N Engl J Med; 3: 271- 278

7. Mauri C, Menon M. (2015) The expanding family of regulatory B cells. Int Immunol; 27 10:479-486.

8. Mizoguchi A, Mizoguchi E, Takedatsu H, et al (2002) Chronic intestinal inflammatory condition generates IL-10-producing regulatory B cell subset characterized by CD1d upregulation. Immunity; 16 : 219-230.

9. Togashi Y, Shitara K, andNishikawa H. (2019) Regulatory $T$ cells in cancer immunosuppression implications for anticancer therapy. Nature reviews Clinical Oncology; 16: 356-371.

10. Blair PA., Nore na LY, Flores-Borja F, et al (2010) $\mathrm{CD} 19^{+} \mathrm{CD} 24^{h i} \mathrm{CD} 38^{h i} \mathrm{~B}$ cells exhibit regulatory capacity in healthy individuals but are functionally impaired in systemic lupus erythematosus patients. Immunity; 32: 129-140.

11. Byrne SN, Halliday GM. (2005) B cells activated in lymph nodes in response to ultraviolet irradiation or by interleukin-10 inhibits dendritic cell induction of immunity. J Invest Dermatol; 124:570-578.

12. Kessel A, Haj T, Peri R, et al (2012) Human $\mathrm{CD} 19^{+} \mathrm{CD} 25^{\text {high }} \mathrm{B}$ regulatory cells suppress proliferation of $\mathrm{CD}^{+} \mathrm{T}$ cells and enhance Foxp3 and CTLA-4 expression in T-regulatory cells. Autoimmunity Reviews; 9: 670-677.

13. Pylayeva-Gupta Y, Das S, Handler JS, et al (2016) IL35- Producing B Cells Promote the Development of Pancreatic Neoplasia. Cancer discovery; 6: 247255.

14. National Comprehensive Cancer Network. (2018) NCCN "Clinical Practice Guidelines in Oncology" Breast cancer, NCCN; 1-209

15. Riedhammer C, Halbritter D, Weissert R. (2016) Peripheral Blood Mononuclear Cells: Isolation, Freezing, Thawing, and Culture. Methods Mol Biol; 1304:53-61.

16. Lighaam LC, Unger PA, Vredevoogd DW, et al. (2018) In vitro-Induced Human IL-10+B Cells Do Not Show a Subset-Defining Marker Signature and Plastically Co-express IL-10 with Pro-Inflammatory Cytokines. Frontiers in Immunology; 9:1913.

17. Gabr A, Razek K, Atta H, et al (2016) Demographic Characteristics and Clinico-Pathological Presentation of Breast Cancer Female Patients in South Egypt Cancer Institute (2005-2012). Oncology; 1:6. 
18. Mathers CD, Bernard C, Iburg KM, et al (2003) Global burden of disease in 2002: data sources, methods and results. Geneva: World Health Organization; 54:1-118.

19. Makar W. (2019) Clinicopathological Characteristics and Survival of Triple-Negative Breast Cancer Patients: A single Institution Study from Egypt. Research in Oncology; 15: 31-34.

20. Gihan I G., Mohamed M B., Ibrahim K., et al (2019) Geospatial Analysis of Breast Cancer in Alexandria: Application of a Novel Public Health Tool. The Egyptian Journal of Community Medicine; 37: 2736.

21. Omar S, Khaled H, Gaafar R, et al (2003) Breast cancer in Egypt: a review of disease presentation and detection strategies. East Mediterr Health J 2003; 9: 448-63.

22. Mouttet D, Laé M, Caly, Gentien D, et al (2016) Estrogen-Receptor, Progesterone-Receptor and HER2 Status Determination in Invasive Breast Cancer, Concordance between ImmunoHistochemistry and MapQuant ${ }^{\mathrm{TM}}$ Microarray Based Assay. PLoS One; 11:2e0146474.

23. Yamauchi H and Hayes DF. (2018) HER2 and predicting response to therapy in breast cancer; UpToDate website. Https://www.uptodate.com/ contents/her2-and-predicting-response-to-therapy -in-breast-cancer. Last updated Sept 05. Accessed July 31, 2019.
24. Fremd C, Schuetz F, Sohn C, et al (2013) B cellregulated immune responses in tumor models and cancer patients. Oncoimmunology; 1:2e25443.

25. Tsuda B, Miyamoto A, Yokoyama K, et al (2018) Bcell populations are expanded in breast cancer patients compared with healthy controls. Breast Cancer; 25: 284-291.

26. Zhou J, Min Z, Zhang D, et al (2014) Enhanced frequency and potential mechanism of $B$ regulatory cells in patients with lung cancer. J Transl Med; 12:304.

27. Hetta, HF., Mekky, M A., Zahran, A M., et al (2020) Regulatory B Cells and Their Cytokine Profile in HCV-Related Hepatocellular Carcinoma: Association with Regulatory $\mathrm{T}$ Cells and Disease Progression. Vaccines (Basel); 8(3):380.

28. Zhifang Chen, Yuejie Zhu, Rong Du, et al (2019) "Role of Regulatory B Cells in the Progression of Cervical Cancer", Mediators of Inflammation, Article ID 6519427, 8 pages.

29. Mehdipour F, Razmkhah M, Hosseini A. (2016) Increased B Regulatory Phenotype in NonMetastatic Lymph Nodes of Node-Positive Breast Cancer Patients, Scand. J Immunol; 83:3:195-202.

30. Murakami Y, Saito H, Shimizu S et al (2019) Increased regulatory $B$ cells are involved in immune evasion in patients with gastric cancer. Sci Rep; 9:13083. 